\title{
INDUSTRIAL GROUPINGS AND FOREIGN DIRECT INVESTMENT
}

\author{
Bruce A. Blonigen ${ }^{\mathrm{a},{ }^{*}}$, Christopher J. Ellis ${ }^{\mathrm{b}}$, Dietrich Fausten ${ }^{\mathrm{c}}$ \\ ${ }^{a}$ University of Oregon and NBER, Department of Economics, Eugene, OR 97403-1285 \\ ${ }^{b}$ University of Oregon, Department of Economics, Eugene, OR 97403-1285 \\ ${ }^{c}$ Monash University, Department of Economics, Clayton 3168, Victoria, Australia
}

Revised Draft: March 2003

\begin{abstract}
We explore worldwide foreign direct investment location decisions by Japanese manufacturing firms from 1985 through 1991. Our conditional logit estimates provide evidence that firms' location decisions are affected by membership in either vertical or horizontal keiretsu. Consistent with previous studies that stress agglomeration effects on firms' location decisions, we find that the stock of investment in a region by a firm's vertical keiretsu partners increases the probability of location. Further, we find that the recent flow of investment into a region by a firm's horizontal keiretsu partners increases the probability of investment to the region, providing evidence of networking effects.
\end{abstract}

Keywords: Multinational Enterprises; Networking; Keiretsu; Agglomeration. JEL Classification: F23, G3.

* The authors thank Ron Davies, James Rauch and anonymous referees for helpful comments. Blonigen gratefully acknowledges financial assistance from a University of Oregon Richard A. Bray Award.

Corresponding author: tel.: 541-346-4680; Fax: 541-346-1243.

E-mail addresses: bruceb@oregon.uoregon.edu (B. A. Blonigen), cjellis@oregon.oregon.edu (C. J. Ellis), dietrich.fausten@buseco.monash.edu.au (D. Fausten). 


\section{Introduction.}

It has frequently been suggested that firms in the large industrial groupings of Japan and Korea, known respectively as keiretsu and chaebol, may behave differently than their US or European counterparts in a number of dimensions. A small set of papers in recent years have examined whether membership in such groupings affects firms' foreign direct investment (FDI) decisions, with a particular focus on the effect of keiretsu groupings on Japanese FDI activity. The majority of papers on this topic have examined the effect of vertical keiretsu groupings, where upstream suppliers are centered around a large downstream manufacturer. As detailed in Head, Ries, and Swenson (1995), significant agglomeration externalities are likely to be present for firms in vertical keiretsu groupings. Suppliers work closely with downstream firms on designing specialized components and often provide just-in-time delivery of supplies. Thus, geographic proximity enhances the efficiency of such arrangements, giving firms incentives to locate their FDI in the same region. Head, Ries and Swenson (HRS) empirically examine Japanese FDI in the U.S. and find that a greater existing stock of a Japanese firm's own vertical keiretsu partners in a particular U.S. state makes that firm more likely to locate in that state as well. However, they find that this vertical keiretsu effect is largely due to the automobile sector, and is no longer present when observations from this sector are excluded from their sample. $^{1}$

The other major form of industrial grouping in Japan is the horizontal keiretsu. These are groupings of firms in often-unrelated industries that are centered on a large bank. There are three features of horizontal keiretsu that observers have pointed out may be important for

\footnotetext{
${ }^{1}$ Belderbos and Carree (2002) perform a similar analysis to HRS, but do so using data on FDI into China by Japanese firms. As HRS found for Japanese automobile-related FDI into the U.S., Belderbos and Carree find significant positive effects of existing vertical keiretsu member presence on Japanese electronic firms' location decisions in China, which is consistent with an agglomeration externalities motivation. Other studies have found
} 
economic behavior: 1) cross-ownership between partner firms, where a group bank holds a significant share of the group-member firms' equity, and these member firms hold substantial equity positions in each other; 2) potentially easier terms of credit for members from the keiretsu-affiliated bank, both due to a reduction in the costs of monitoring and the discipline of repeat financing; 3) organized meetings amongst major keiretsu firms often called Presidential Council meetings which potentially facilitate the exchange of information and the coordination of actions.

With respect to FDI activity, researchers have focused on easier credit terms as the feature of horizontal keiretsu that potentially leads to greater firm investment, including FDI. The tests employed examine whether membership in any horizontal keiretsu increases a firm's likelihood of FDI, since such membership should give the firm cheaper financing of such investment, ceteris paribus. ${ }^{2}$ The evidence for these effects of horizontal keiretsu membership is much more mixed than for vertical keiretsu. ${ }^{3}$

In addition to mixed empirical results, a recent paper by Miwa and Ramseyer (2002) argues that economic effects stemming from the features of horizontal keiretsu described above are more myth than reality. They point out that the vast majority of financing by Japanese firms in keiretsu groupings comes from non-keiretsu financial institutions, and this share has been increasing over time. This runs counter to the notion that horizontal keiretsu firms rely on their keiretsu bank for easier credit terms and may explain why previous studies have only found

positive effects of vertical keiretsu groupings on Japanese FDI activity using alternative estimation strategies, including Belderbos and Sleuwaegen (1996), Yui and Pugel (1995), and Ryan (2001).

${ }^{2}$ A horizontal keiretsu membership dummy is sometimes interacted with variables that measure how creditconstrained the firm may be, to see if membership is more beneficial for such firms in the keiretsu.

${ }^{3}$ Belderbos and Sleuwegen (1996) find that horizontal keiretsu membership makes Japanese firms more likely to be multinational enterprises and that this membership effect is most significant for those firms that are credit constrained. Ryan (2001), however, finds only weak evidence for a horizontal keiretsu membership effect, whereas McKenzie finds no evidence that such membership affects the likelihood of FDI into various regions by Japanese firms. 
mixed evidence that horizontal keiretsu membership increases (foreign) investment. ${ }^{4}$ Likewise, Miwa and Ramseyer show that cross-shareholding arrangements are much lower than one would expect, particularly between the non-financial members of these horizontal keiretsu. Finally, Miwa and Ramseyer dispute the notion that the Presidential Council meetings by executives of the keiretsu's main members have any influence on behavior by members whatsoever, contending that "scholars who stress their importance have yet to produce a lunch club decision that much mattered." (p. 193)

Of the arguments Miwa and Ramseyer (2002) make to show that horizontal keiretsu are fables, their argument against the effect of Presidential Council meetings is likely the weakest. Even if they are correct that important collusive agreements amongst firms are not forthcoming from such meetings ${ }^{5}$, there is likely a high level of the networking and information exchange that occurs when heads of member firms meet. Such networking connections may have a very substantial role in economic decisions and behavior, as evidenced by recent papers documenting a strong and significant effect of networking connections on international trade flows. ${ }^{6}$ We find these papers compelling, and suggest they serve to answer the obvious response to Miwa and Ramseyer's (2002) criticism, which is to ask why such meetings take place if they serve no purpose.

In this paper, we examine for the first time the potential effect of networking connections through keiretsu relationships on the FDI decisions made by Japanese firms. We hypothesize that if network effects are present then previous FDI activity by a firm's horizontal keiretsu

\footnotetext{
${ }^{4}$ We do not find this argument persuasive. While the share of financing of keiretsu firms' investments by their group-member-bank may be small and falling, what is important is the financing of marginal investments. This may be precisely where the special relationship has greatest impact.

${ }^{5}$ Note that tacit collusive decisions are by their very nature difficult to observe. Thus, it should not surprise us if there are few known examples of obvious lunch club decisions that had an impact.

${ }^{6}$ Such papers include Greif (1993), Gould (1994), Head and Ries (1998), Rauch (1999) and Rauch and Trinidade (2002). Rauch (2001) provides an overview of the theoretical and empirical work in this area.
} 
partners into particular foreign regions will make FDI by the firm into these same regions more likely, because this lowers the necessary costs of information acquisition. Thus, our focus is on whether region-specific horizontal keiretsu activity affects a firm's FDI location decisions. This contrasts with previous studies of FDI by horizontal keiretsu that has examined whether keiretsu membership per se affects a firm's decision to engage in FDI at all.

Similar to HRS, we estimate a Japanese firm's FDI location decision using a conditional logit framework. However, we introduce two important innovations. First, we sample FDI location decisions by Japanese manufacturing firms in the late 1980s and early 1990s across all foreign regions of the world. Second, our sample includes both vertical and horizontal keiretsu, this allows us to examine the potential networking effects of horizontal keiretsu, while controlling for agglomeration benefits that are a strong feature of vertical keiretsu linkages.

We find that agglomeration externalities from vertical keiretsu are important considerations for Japanese investment location decisions worldwide. The stock of investment in a region by a firm's vertical keiretsu members increases the probability of the firm's location in that region. For example, our estimates suggest that the existence of investment by vertical keiretsu members of 500 employees or more in a region increases the firm's probability of location in that region by over $50 \%$. The agglomeration impact of unrelated firm location by Japanese manufacturing firms in the same industry is also statistically significant, though less than half the magnitude of the vertical own-keiretsu effects. These agglomeration results are consistent with HRS, but importantly generalize these results for Japanese location decisions worldwide, not just for regions in the U.S. Additionally, our vertical keiretsu effects are robust to the exclusion of automobile-centered vertical keiretsu, which was not true for HRS. 
We also explore and find supportive evidence for the idea that investment activity by related horizontal keiretsu members affects worldwide investment location decisions of Japanese firms. We find that recent (previous-year) investment activity by horizontal keiretsu partners leads to a greater probability of location in the same region by a firm. ${ }^{7}$ For example, previousyear investment activity of horizontal partners of at least 100 employees increases a firm's likelihood of location in that region by almost $20 \%$. We attribute these effects to the networking and information sharing that occurs between members of horizontal keiretsu, as such information sharing can yield cost-savings to a newly-locating firm. Consistent with this interpretation, we find such horizontal keiretsu effects are substantially larger for the Presidential Council firms in the most closely-knit horizontal keiretsu - precisely where one would expect such information sharing to be the greatest. We further find that the horizontal keiretsu effects only occur with respect to recent investment activity, suggesting that information relevant for entry decisions depreciates with the age of the previous investments. These results provide the first systematic evidence for the networking effect of business groups on FDI decisions of which we are aware. ${ }^{8}$ By examining the effect of recent investment activity by horizontal keiretsu members across regions, we better identify this networking effect, in contrast to previous studies that examined only whether membership in a horizontal keiretsu per se affects investment decisions.

The rest of the paper proceeds as follows. The next section outlines our empirical methodology that starts with the framework of HRS and modifies it to allow for the effects of networking and information-sharing on FDI location decisions. Section 3 describes our sample of investment decisions by Japanese manufacturing firms from 1985 through 1991 and

\footnotetext{
${ }^{7}$ Previous year's investments presumably reveal the most up to date and thus useful information.

${ }^{8}$ Using empirical methods similar to Rauch and Trindade's (2002) study of bilateral trade patterns, Tong (2001) finds evidence that greater ethnic Chinese networks increase FDI activity between countries. In contrast, we are examining network effects that occur through more formal business groups.
} 
construction of our agglomeration and networking/information variables. Section 4 then presents out conditional logit estimates and sensitivity tests before a final section concludes.

\section{Empirical Methodology}

We follow HRS in specifying a Japanese firm's FDI location decision as one that can be modeled using a conditional logit specification. Assuming production is Cobb-Douglas and that agglomeration externalities enter the production function in a multiplicative fashion similar to infrastructure and other inputs, then a firm's profitability for producing in a particular region is a log-linear function of the agglomeration measures, infrastructure measures and factor prices. Thus, the profitability of region $r$ for investor $j$ may be represented as

$$
\theta_{\mathrm{r}}+\alpha_{\mathrm{i}} \ln \mathrm{A}_{\mathrm{j}, \mathrm{r}}^{\mathrm{i}}+\varepsilon_{\mathrm{j}, \mathrm{r}},
$$

where $\mathrm{A}^{\mathrm{i}}$ represents agglomeration externalities from source $i, \theta_{r}$ represents region-specific effects, and $\varepsilon_{\mathrm{j}, \mathrm{r}}$ is an error term. Region-specific effects are important as they control for a wide variety of potentially important characteristics of a region that are both difficult to measure precisely and are hard to observe, but none-the-less may make it more or less attractive to investors. Such characteristics range from infrastructure and input prices to labor force characteristics and amenities of the natural environment. ${ }^{9}$

HRS examine four sources of potential regional agglomeration externalities $\left(\mathrm{A}^{\mathrm{i}}\right)$ in their empirical analysis: 1) from U.S. domestic firms in the same 4-digit Standard Industrial Classification (SIC) industry ( $\mathrm{A}^{\mathrm{US}}$ ) in the region, 2) from other Japanese firms in the same industry $\left(\mathrm{A}^{\mathrm{J}}\right)$ in the region, 3) from Japanese firms who belong to the firm's vertical keiretsu $\left(A^{G}\right)$ in the region, and 4) from agglomeration in states that border the region $\left(A^{B}\right)$. In our

\footnotetext{
${ }^{9}$ The investment decisions we examine will also span a number of years, so we initially assume that these regionspecific variables are time-invariant. However, below we explore inclusion of region-year-specific effects.
} 
analysis, we include variables to measure the second and third agglomeration externalities in similar fashion to HRS. The first source of agglomeration (U.S. domestic industry presence in a U.S. region) is obviously not directly comparable because we are examining worldwide FDI activity of Japanese firms, not just the U.S. component. An analogue to this first HRS agglomeration variable would be a proxy for domestic activity in the region/country for the same SIC industry. However, it is impossible to obtain comparable data on such activity across regions of the world for detailed 4-digit SIC industries. Since our data span just seven years, we initially assume that changes in such aggregate activity remain constant across regions and are then subsumed into the region effects, though we show that are estimates are robust to including region-year effects as well which obviously relaxes this assumption. Examination of the fourth source of agglomeration externalities (effects from border states) is not a significant issue for our analysis because we examine Japanese investment into much more aggregate country/region groupings than HRS. Thus, we do not include such measures in our analysis.

Unlike HRS, our analysis examines not only agglomeration effects from vertical keiretsu relationships, but also the potential for networking effects associated with horizontal keiretsu. We hypothesize that networking connections with firms already in a particular region provide important investment information to an investing firm. This information can lower its costs of production in that particular region. For example, such information could allow the firm to better site its investment in a more cost-effective location and/or garner more favorable tax and regulatory treatment. ${ }^{10}$

\footnotetext{
${ }^{10}$ These are examples of how such information can lead to reductions in variable costs, since it is a production function that is the theoretical framework for the conditional logit specification we employ. Networking and information costs may also lower one-time fixed costs of FDI location as well. Our estimates may be capturing these one-time savings though we do not model them formally.
} 
Another source of cost-reducing information not explored by HRS is the firm's own experience. Shaver, Mitchell, and Yeung (1997) find that FDI by firms into a region for which they have prior FDI experience is more likely to survive than FDI by first-time entrants. ${ }^{11}$ They attribute these effects to informational spillovers that occur within the firm. Such within-firm informational spillovers should reduce the cost of operation in regions where a firm has prior experience and make such a location more attractive than others, ceteris paribus.

Given these considerations, we can modify equation (1) to include these two sources of networking/information spillovers, membership of a horizontal keiretsu and the firm's own experience:

$$
\theta_{\mathrm{r}}+\alpha_{\mathrm{i}} \ln \mathrm{A}_{\mathrm{j}, \mathrm{r}}^{\mathrm{J}}+\eta_{\mathrm{i}} \ln \mathrm{A}_{\mathrm{j}, \mathrm{r}}^{\mathrm{G}}+\beta_{\mathrm{i}} \ln \mathrm{HK}_{\mathrm{j}, \mathrm{r}}+\theta_{\mathrm{i}} \ln \mathrm{PE}_{\mathrm{j}, \mathrm{r}}+\varepsilon_{\mathrm{j}, \mathrm{r}},
$$

where $\mathrm{HK}$ is a variable capturing the potential for information sharing through horizontal keiretsu relationships with other firms in region $r$, and PE is a variable measuring the firm's own previous experience in region $r$, which can provide evidence on intra-firm information sharing.

One potential difference between agglomeration effects from vertical keiretsu relationships and networking information effects from horizontal keiretsu groupings is that while agglomeration effects clearly relate to stocks of related firms, information effects may be more directly tied to recent flows of investment into a region, not stocks. Firms that have most recently invested in a region should have better current information for potential investors. As a result, we will examine both stock and recent flow measures of agglomeration and informationsharing variables in our empirical analyses. Our maintained hypothesis is that stock measures best capture agglomeration effects, and flow measures best capture information-sharing effects.

\footnotetext{
${ }^{11}$ In a related vein, Yu (1990), Kogut and Chang (1991), Hennart and Park (1994), Belderbos (1997), and Blonigen (2002) are examples of papers that have found that firms are more likely to invest abroad if they have previous FDI experience.
} 
Of course, there may be agglomeration externalities that stem from what we are terming information variables. For example, agglomeration externalities may exist between horizontal keiretsu firms, even though these horizontal keiretsu firms are almost always in different industries and, likewise, agglomeration externalities may stem from a firm's own previouslyestablished plants in a region. However, we expect agglomeration effects from these sources to be relatively minimal and outweighed by the informational effects. Similarly, some information effects may stem from what we are terming agglomeration variables. As our analysis below will show, these effects sort out well when comparing flow versus stock measures of our agglomeration and information variables.

\section{Data and Variable Construction}

We use the publication, Japanese Overseas Investment: A Complete Listing by Firms and Countries 1992/93 (English version) published by Toyo Keizai Inc., for data on Japanese FDI and foreign affiliate activity. ${ }^{12}$ This publication reports information from a census of all Japanese-owned subsidiaries, and includes location, parent firm, establishment date, employment, and type of investment (greenfield or acquisition). These data are updated and published semiannually, however, with the exception of the 1984 report, no other years provide an English version. The 1992/93 census comes at the end of a substantial wave of FDI activity by Japanese firms in general, which began in the mid-1980s and subsided in the early 1990s. ${ }^{13}$ We analyze FDI location decisions by all Japanese manufacturing firms for the period 1985 through 1991, the last full year of the census information.

\footnotetext{
${ }^{12}$ We gratefully thank Keith Head and John Ries at the University of British Columbia for sharing their electronic version of these data.

${ }^{13}$ Over half of the total Japanese affiliates reported in Toyo Kezei (1993) were established during the 1985-1991 period.
} 
We categorize investment locations into eleven countries/regions that comprise all possible world locations: the nine major destination host countries, an all-other developed country region, and an all-other less-developed country region. The nine major destination countries are Germany, Indonesia, Korea, Malaysia, Singapore, Thailand, Taiwan, the United Kingdom, and the United States. With 1485 investment decisions in our sample from 1985 through 1991 across 11 possible destinations, our data consist of a total of 16,335 observations.

Table 1 reports the relative frequency of Japanese FDI established in the eleven locations. As can be seen from Table 1, the United States is the destination that receives the most Japanese FDI, accounting for $29.5 \%$ of total affiliates and $37.1 \%$ of foreign-affiliate employment. Despite this, Japanese FDI is dispersed fairly widely across various destinations, with many top destinations in Southeast Asia.

To proxy for agglomeration effects, HRS uses counts of establishments/plants. One concern with counts is that it assumes comparable size of such establishment/plants. As Table 1 shows, average plant size in terms of employees can be quite different even at the aggregate country level, with a low of 187.4 employees per affiliate in Singapore to a high of 434.5 employees per affiliate in Germany. Given that the size of the affiliate likely affects the expected agglomeration and information effects from such an affiliate, we use the number of employees to proxy for agglomeration and information effects rather than counts of establishments/plants. Thus, the number of employees by firms in the same 4-digit SIC industry in the region $r$ (excluding the firm itself) proxies for $\mathrm{A}_{\mathrm{j}, \mathrm{r}}^{\mathrm{J}}$ and the number of employees by members of the firm's same vertical keiretsu in region $r$ (again excluding the firm itself) proxies for $\mathrm{A}_{\mathrm{j}, \mathrm{r}}^{\mathrm{G}}$. Similarly for the information-related variables, the number of employees by members of the firm's same horizontal keiretsu (excluding the firm itself and any firms in the same 
industry) in region $r$ proxy for $\mathrm{HK}_{\mathrm{j}, \mathrm{r}}$, and the number of employees by the firm itself in region $r$ proxy for $\mathrm{PE}_{\mathrm{j}, \mathrm{r}}$. As in $\mathrm{HRS}$, we add one to these employment measures of agglomeration and/or information to avoid taking the log of zero.

HRS measures agglomeration variables as stocks, adding up the number of affiliates from all previous years. As mentioned above, this seems most appropriate for agglomeration variables, but is perhaps less appropriate for information variables, as the quality of information may depend on recent experiences. Thus, we consider measures that include only the previousyear activity (flows) and ones that measure the stock of activity, ${ }^{14}$ expecting that the evidence for the information variables is stronger when considering flow measures and vice versa for the agglomeration variables.

One measurement problem we face, regardless of whether counts of establishments or employees are used, is that we have these counts as of 1991-92 only, the year of the survey. Thus, when we include observations prior to these years, we are assuming both no exits between those years and the end of the sample, and, constant employee levels. Head and Ries (2002) made the same assumptions in using this database to examine skill upgrading by Japanese firms when investing abroad. Having our sample consider FDI activity only as far back as 1985 mitigates this problem to some extent, especially when using previous-year flow data for our regressors. In fact, we get qualitatively similar coefficient estimates to those reported below when we restrict our sample to just 1990 and 1991, the two most recent years of our sample, although the loss of observations inflates standard errors somewhat. The use of stock data for our measures is more problematic as it necessarily assumes no exit or changes in employee levels for Japanese manufacturing affiliates have ever taken place. Of course, the vast majority 
of Japanese FDI occurred in the 1980s and 1990s (over 50\% during the years of our sample, 1985-1991) which helps in making the 1992 numbers a reasonable approximation for most of the sample. With stock variables, counts of establishments may have an advantage in that exits of Japanese affiliates are a rare event, while changes in employee levels may be more common. Our results with stock variables are robust to whether one uses counts of establishments or number of employee measures. Employee measures, however, always outperform counts-ofestablishment measures in terms of the attained log likelihood and goodness of fit measures. Thus, our specifications below use employee measures.

We use Industrial Groupings in Japan 1988/89, published by Dodwell Marketing Consultants to categorize Japanese firms into keiretsu. There are six main horizontal keiretsu (DKB, Fuyo, Mitsubishi, Mitsui, Sanwa, and Sumitomo) with two lesser horizontal keiretsu (IBJ and Tokai). There are a number of vertical keiretsu, largely centered around major electronics and automobile firms, including Hitachi, Matsushita, Nissan, and Toyota. For horizontal keiretsu, the publication also lists which firms are Presidential Council members. This will allow us to examine in our analysis below whether the horizontal keiretsu effects on investment are larger for these firms, as one would expect if the networking information hypothesis is correct. Table 2 displays summary statistics for our regressors.

\section{Results}

Columns 1 and 2 of Table 3 present our conditional logit maximum likelihood estimates for Japanese manufacturing FDI when we use the previous year's investment flow and total FDI stocks, to measure our agglomeration and information variables respectively. The first two rows

\footnotetext{
${ }^{14} \mathrm{We}$ also tried measures that examined the most recent 5 -year activity, which predictably gave coefficient estimates that were somewhere between the one-year flow and stock measures. We do not report these for the sake of brevity.
} 
report coefficient estimates for the agglomeration measures, previous investment by vertical keiretsu members and previous investment by Japanese firms in the same industry. The second two rows report coefficient estimates for the networking/information variables, previous investment by horizontal keiretsu members and previous investment by the firm. Region dummies are included in both equations and a chi-squared test strongly supports their inclusion.

Comparing the specification with one-year flow measures (column 1) versus stock measures (column 2) provide differences in coefficients as hypothesized. The strongest evidence for the information variables are in the one-year flow specification, while the agglomeration variables are strongest when stock data are used. The previous-year flow of investment by horizontal keiretsu members affects current year location decisions in a statistically significant manner, providing the strongest evidence to date that networking effects influence FDI behavior. As one would expect, the effect of the firm's own recent investment experience is even stronger, with a coefficient that is roughly double the magnitude of the horizontal keiretsu effect. In the stock specification in column 2, the coefficient on both of these variables falls and the effect of horizontal keiretsu investment stock is not statistically significant.

The results for the agglomeration variables are symmetrically opposite. Both variables come in strongly when measured in stocks, as in HRS. Also consistent with HRS, we find that the agglomeration effect from vertical keiretsu member investment is stronger than the agglomeration effect from investment by other Japanese firms in the same industry. In this way, our results generalize HRS' conclusions about the effect of agglomeration effects on Japanese FDI location to a sample that considers Japanese FDI to all world locations, not just regions in the United States. Interestingly, our vertical keiretsu effects are robust to excluding the automobile-centered keiretsu, with the coefficient in column 2 changing from 0.119 to 0.113 and 
remaining statistically significant at the $99 \%$ confidence level. This was not true with HRS' analysis of location in U.S. regions, where vertical keiretsu effects were much smaller and statistically insignificant when excluding auto-related investments.

While we can tell from the coefficient estimates that the marginal effects of the information variables are in the same range as the agglomeration variables, it is not straightforward to interpret the magnitude of coefficient estimates in a conditional logit model. However, as shown in HRS, it can be shown that the average probability elasticity (over all choosers and location choices) for a given regressor can be expressed as the ratio, $\mathrm{S}-1 / \mathrm{S}$, multiplied by the regressor's associated coefficient, where $\mathrm{S}$ is the number of location choices. Since there are eleven location choices in our specification, the elasticity of the probability of a location being chosen with respect to a regressor is the regressor's associated coefficient multiplied by 0.91 . At first glance this makes the elasticities associated with the coefficient estimates seem quite small, and, indeed, they are significantly smaller than those reported by HRS. However, our use of employment data rather than counts of affiliates means that our regressors have significant variation as seen in Table 2. For example, a standard deviation increase in the horizontal keiretsu investment regressor (using one-year flow data) represents an increase of $256 \%$ of the sample's mean value of this regressor. In fact, for all but one regressor (investment stock of other firms in the industry) the standard deviation is at least $100 \%$ of the mean. This suggests that thinking about the marginal effects for a doubling $(100 \%)$ increase in a variable is a reasonable metric for evaluating the economic significance of these variables on Japanese manufacturing location decisions. By this metric, the estimated coefficients suggest small, though not inconsequential impacts. For example, a doubling of previous-year investment by horizontal keiretsu members in an average region increases the probability of FDI location 
there by $3.1 \%$. Similarly, there is a $6.9 \%$ increase in location probability for a doubling of previous-year investment in the region by the firm itself. One potential reason for fairly small elasticities is that there are a large number of observations with little or no previous investment and a smaller number of observations where investment is relatively large. Thus, interpreting estimated elasticities as relating to a regressor distribution that is relatively continuous may be misleading.

An alternative is to specify our regressors in a more dichotomous fashion. Another reason to explore such a specification is that agglomeration or information effects may be relatively inconsequential unless there is some minimum level of investment. In columns 3 and 4 of Table 3 we specify our agglomeration and information variables as binary variables that take the value of " 1 " if the previous investment (flow or stock) in a regions was greater than a certain threshold and "0" if not. For previous-year flow measures in column 3, the threshold we use is 100 employees, whereas for investment stock measures in column 4, the threshold is 500 employees. The pattern of coefficient signs and significance in columns 3 and 4 are almost identical to those in columns 1 and 2. A number of alternative threshold levels for both the flow and stock measure were tried and yielded qualitatively similar results. ${ }^{15}$ Thus, our results are robust to this alternative specification.

However, the marginal effects are easily interpretable in this binary specification as the change in the probability of location in a region when the threshold investment level occurs. For example, if the previous-year investment flow into a particular region by a firm's horizontal keiretsu members was greater than 100 employees, the probability of location in that region by the firm goes up $19.2 \%$. Previous-year investment greater than 100 employees by the firm itself

\footnotetext{
15 These alternative thresholds were 0, 50, and 250 employees for the flow measure, and 0, 250 and 1000 employees for the stock measure.
} 
raises the location probability $43.5 \%$. Thus, the magnitudes of the marginal effects from this specification show that both the networking/information and agglomeration effects are economically quite significant.

We interpret the positive coefficient on the horizontal keiretsu investment measure (oneyear flows) as evidence for information externalities due to networking connections. However, some horizontal keiretsu are considered to be more tightly organized than others, and, additionally, firms within horizontal keiretsu may vary in how closely connected they are with other firms in the group. Thus, we expect that networking/information effects are larger the more closely organized the horizontal keiretsu and the more closely connected the firm is to its horizontal keiretsu. Dodwell Marketing Consultants (1990) indicates that of the eight horizontal keiretsu, the Mitsubishi, Mitsui, and Sumitomo keiretsu are most closely connected (e.g., see discussion on pp. 44, 58 and 73). The other keiretsu were largely formed as more looselyconnected groups after WWII. ${ }^{16}$ Additionally, Dodwell lists the firms that participate in the Presidential Council meetings, generally the largest and most influential companies in the group. ${ }^{17}$ This information allows us to examine whether the networking/information effects are larger for such firms and keiretsu. We do this by adding a term that interacts our horizontal keiretsu measure with a binary variable that takes the value of "1" when the firm is a Presidential Council member in one of the three "cohesive" horizontal keiretsu listed above.

Columns 1 and 2 in Table 4 provides results when we add this new interaction term to our base specification in columns 1 and 2 of Table 3. As expected, the coefficient on this

\footnotetext{
16 In contrast, the Mitsubishi, Mitsui, and Sumitomo keiretsu are companies that were formerly organized as zaibatsu before WWII. These zaibatsu were powerful family enterprises that rose to prominence in Japan after the Meiji restoration in 1868. These zaibatsu were formally dismantled in the Allied occupation after WWII, but were allowed to reorganize as keiretsu in the 1950s.

17 As of 1988/89, the Mitsubishi Presidential Council was comprised of 29 of the keiretsu's 160 firms, the Mitsui Presidential Council was the top 24 of 120 firms and the Sumitomo Presidential Council was the top 20 of its 130 firms. (Dodwell Marketing Consultants, 1990)
} 
interaction term is positive and statistically significant in the one-year flow specification, with the coefficient indicating the extra networking/information effect that is enjoyed by these Presidential Council firms in these cohesive keiretsu groupings. The separate horizontal keiretsu coefficient is now reduced and statistically insignificant, suggesting that the networking effects found in Table 3 are generally driven by this subset of firms. As before, when we use stock data for our measures, the coefficient on both horizontal keiretsu terms falls and the interaction term is no longer statistically significant. We interpret this as further evidence that a networking interpretation is appropriate for explaining the positive coefficient on the horizontal keiretsu investment measures.

One potential source of omitted variable bias is the effect of macroeconomic events, such as exchange rate movements and economic growth in the potential host country, which may affect the desirability of locations. A general way to control for this is to employ region-year specific constants rather than just region specific constants. This would also control for systematic location of non-Japanese investment to the region, something that we have not controlled for to this point and which could also be a source of agglomeration (or information) externalities. Columns 3 and 4 of Table 4 provide results when we add region-year specific constants to our specification estimated in columns 1 and 2 of Table 4 . Our estimates are essentially unchanged from specifying region-year versus region specific constants.

A final issue with any conditional logit estimates is the appropriateness of the assumption of the independence of irrelevant alternatives (IIA). The common way to evaluate this is to statistically test whether coefficient estimates are relatively unchanged when various subsets of choices are excluded. For our sample, one obvious concern would be whether the parameters affecting location decisions are the same between the less-developed country (LDC) locations 
and developed country locations. However, Hausman tests fail to reject the null hypothesis of identical coefficients between an LDC sample and the full sample, affirming the IIA assumption. Another obvious concern is the U.S. as a destination choice, as it easily represents the most frequent location choice for Japanese manufacturing during the sample years. A Hausman test does not support the IIA assumption when one drops the U.S. as a location choice. However, separate tests on a coefficient by coefficient basis, finds no significant difference in the vertical and horizontal keiretsu variables, the focus of our study, when comparing a specification that excludes the U.S. to the full specification. Instead, the information effect of the firm's own experience and the industry-level agglomeration effects are almost twice as large for a specification excluding the U.S. as a choice.

\section{Conclusion}

This paper finds evidence that Japanese business groups (keiretsu) provide networking and information externalities that affect the FDI location decisions of partner firms. Previous work on Japanese business groups and FDI decisions has focused on vertical keiretsu, showing that location of FDI by a firm in a particular region is positively correlated with the existing FDI in that region by members of the firm's vertical keiretsu. The results from these studies provide evidence of agglomeration externalities. We extend this literature to examine more closely the effect of horizontal keiretsu, large firms in primarily unrelated fields that are tied to a major bank and whose leaders systematically meet in Presidential Council or "lunch club" meetings. Such meetings provide opportunities for information-sharing and networking, which can affect these firms' economic activity, including their foreign investment decisions. In particular, such information-sharing may allow a firm to better navigate a foreign country's tax/regulatory 
environment and better site its plant, lowering initial setup costs, as well as operating costs. This would then make the firm's location in the region more likely.

Using a sample of all Japanese manufacturing investments from 1985 through 1991, we find evidence that recent FDI activity in a region by a firm's horizontal keiretsu members increases the probability of location in that region by the firm, even after controlling for other factors including sources of agglomeration externalities. As one would expect, this effect is much stronger for horizontal keiretsu firms that regularly participate in the Presidential Council meetings in the most closely-knit horizontal keiretsu groups. A by-product of our analysis is that we confirm agglomeration externalities of vertical keiretsu relationships found by previous studies, but for a choice set that encompasses locations across the world, not just within a particular country, such as the United States or China. 


\section{References}

Belderbos, R., 1997. Antidumping and tariff jumping: Japanese firms' DFI in the European Union and the United States. Weltwirtschaftliches Archiv, 133, 419-457.

Belderbos, R., Sleuwaegen, L., 1996. Japanese firms and the decision to invest abroad: Business groups and regional core networks. Review of Economics and Statistics 77, 214-220.

Belderbos, R., Carree, M., 2002. The location of Japanese investments in China: Agglomeration effects, keiretsu, and firm heterogeneity. Journal of the Japanese and International Economies $16,194-211$.

Blonigen, B.A., 2002. Tariff-jumping antidumping duties. Journal of International Economics 57, 31-49.

Dodwell Marketing Consultants, 1990. Industrial groupings in Japan, 1988/89. Dodwell Marketing Consultants, Tokyo.

Ellis, C.J., Fausten, D., 2002. Strategic FDI and industrial ownership structure. Canadian Journal of Economics 35, 476-494.

Gould, D.M., 1994. Immigrant links to the home country: Empirical implications for U.S. bilateral trade flows. Review of Economics and Statistics 76, 302-316.

Greif, A., 1993. Contract enforceability and economic institutions in early trade: The Maghribi traders' coalition. American Economic Review 83, 525-548.

Head, K., Ries, J., 1998. Immigration and trade: Econometric evidence from Canada. Canadian Journal of Economics 31, 47-62.

Head, K., Ries, J., Swenson D., 1995. Agglomeration benefits and location choice: Evidence from Japanese manufacturing investments in the United States. Journal of International Economics 38, 223-247.

Head, K., and Ries, J., 2002. Offshore production and skill upgrading by Japanese manufacturing firms. Journal of International Economics 58, 81-105.

Hennart, J.-F., and Y.-R. Park, "Location, governance, and strategic determinants of Japanese manufacturing investments in the United States. Strategic Management Journal 15, 419-436.

Hoshi, T., Kashyap, A., Scharfstein D., 1991. Corporate structure, liquidity, and investment: Evidence from Japanese industrial groups. Quarterly Journal of Economics 66, 33-60.

Kimura, Y., Pugel, T.A., 1995. Keiretsu and Japanese direct investment in US manufacturing. Japan and the World Economy 7, 481-503. 
Kogut, B., Chang S.J., 1991. Technological capabilities and Japanese foreign direct investment. Review of Economics and Statistics 73, 401-413.

Kogut, B., Chang, S.J., 1996. Platform investments and volatile exchange rates: Direct investment in the United States by Japanese electronic companies. Review of Economics and Statistics 78, 221-231.

McKenzie, C.R., 1997. Japanese direct foreign investment: The role of technology and keiretsu. In: Freedman, C. (Ed.), Japanese Economic Policy Reconsidered. Elgar in association with Centre for Japanese Economic Studies (Macquarie University), Cheltenham, U.K., and Northampton, MA.

Miwa, Y., Ramseyer, J.M., 2002. The fable of the keiretsu. Journal of Economic Management and Strategy 11, 169-224.

Rauch, J.E., 1999. Networks versus markets in international trade. Journal of International Economics 48, 7-35.

Rauch, J.E., 2001. Business and social networks in international trade. Journal of Economic Literature 34, 1177-1203.

Rauch, J.E., Trindade, V., 2002. Ethnic Chinese networks in international trade. Review of Economics and Statistics 84, 116-130.

Ryan, Michael J., 2001. The hazards of Japanese foreign direct investment in Europe. Mimeo.

Suzuki, K., 1993. R\&D spillovers and technology transfer among and within vertical keiretsu groups: Evidence from the Japanese electrical machinery industry. International Journal of Industrial Organization 11, 573-591.

Tong, S.Y., 2001. Foreign direct investment and ethnic Chinese networking. Hong Kong Institute of Economics and Business Strategy Working Paper 1024.

Toyo Keizai Inc., 1992. Japanese overseas investment: A complete listing by firms and countries 1992/93. Toyo Keizai Inc., Tokyo.

Yu, C.-M., 1990. The experience effect and foreign direct investment. Weltwirtschaftliches Archiv 126, 561-580. 

Table 1: Japanese industrial and electrical machinery investments from
1985 through 1991, by location.

\begin{tabular}{|c|c|c|c|c|c|}
\hline \multirow[b]{2}{*}{ Country } & \multicolumn{2}{|c|}{ Number of affiliates } & \multicolumn{2}{|c|}{ Affiliate Employees } & \multirow[b]{2}{*}{$\begin{array}{c}\text { Average Plant } \\
\text { Size (in } \\
\text { employees) } \\
\end{array}$} \\
\hline & Number & $\begin{array}{c}\text { Percent of } \\
\text { Total }\end{array}$ & Number & $\begin{array}{c}\text { Percent of } \\
\text { Total }\end{array}$ & \\
\hline Germany & 47 & 3.2 & 20,421 & 4.3 & 434.5 \\
\hline Indonesia & 49 & 3.3 & 17,829 & 3.7 & 363.9 \\
\hline Korea & 73 & 4.9 & 14,756 & 3.1 & 202.1 \\
\hline Malaysia & 114 & 7.7 & 38,387 & 8.0 & 336.7 \\
\hline Singapore & 53 & 3.6 & 9,930 & 2.1 & 187.4 \\
\hline Thailand & 171 & 11.5 & 49,753 & 10.4 & 291.0 \\
\hline Taiwan & 106 & 7.1 & 23,430 & 4.9 & 221.0 \\
\hline United Kingdom & 83 & 5.6 & 21,796 & 4.6 & 262.6 \\
\hline United States & 438 & 29.5 & 177,090 & 37.1 & 404.3 \\
\hline Other Developed Countries & 162 & 10.9 & 38,119 & 8.0 & 235.3 \\
\hline $\begin{array}{l}\text { Other Less-Developed } \\
\text { Countries }\end{array}$ & 189 & 12.7 & 66,115 & 13.8 & 349.8 \\
\hline
\end{tabular}

Table 2: Summary statistics of regressors.

\begin{tabular}{|l|c|c|c|c|}
\hline Variable & Mean & $\begin{array}{c}\text { Standard } \\
\text { Deviation }\end{array}$ & Minimum & Maximum \\
\hline One-Year Flow Measures & & & & \\
\hline Investment by vertical keiretsu members & 0.231 & 1.113 & 0.000 & 8.407 \\
\hline $\begin{array}{l}\text { Investment by Japanese firms in same } \\
\text { industry }\end{array}$ & 1.456 & 2.412 & 0.000 & 8.628 \\
\hline $\begin{array}{l}\text { Investment by horizontal keiretsu } \\
\text { members }\end{array}$ & 0.403 & 1.388 & 0.000 & 9.681 \\
\hline Investment by firm. & 2.316 & 2.765 & 0.000 & 9.683 \\
\hline $\begin{array}{l}\text { Stock Measures } \\
\text { Investment by vertical keiretsu members }\end{array}$ & 0.819 & 2.254 & 0.000 & 9.362 \\
\hline $\begin{array}{l}\text { Investment by Japanese firms in same } \\
\text { industry }\end{array}$ & 3.624 & 3.826 & 0.000 & 10.121 \\
\hline $\begin{array}{l}\text { Investment by horizontal keiretsu } \\
\text { members }\end{array}$ & 2.240 & 2.958 & 0.000 & 9.798 \\
\hline Investment by firm. & 6.346 & 2.542 & 0.000 & 10.514 \\
\hline
\end{tabular}

Notes: All variables are measured in numbers of employees and logged after adding the value of " 1 ", to avoid taking the log of zero. 
Table 3: Conditional Logit Estimates of the Effect of Previous-Year Investment by Keiretsu Members on a Firm's Location Choice.

\begin{tabular}{|c|c|c|c|c|}
\hline \multirow[b]{2}{*}{ Regressors } & \multicolumn{2}{|c|}{$\begin{array}{c}\text { Previous Investments } \\
\text { Measured in Number of } \\
\text { Employees }\end{array}$} & \multicolumn{2}{|c|}{$\begin{array}{l}\text { Previous Investments } \\
\text { Measured as Whether } \\
\text { Large Investment or Not }\end{array}$} \\
\hline & $\begin{array}{c}\text { Previous- } \\
\text { Year Flows } \\
\end{array}$ & Stock & $\begin{array}{c}\text { Previous- } \\
\text { Year Flows } \\
\end{array}$ & Stock \\
\hline \multicolumn{5}{|l|}{ Agglomeration Variables } \\
\hline $\begin{array}{l}\text { Investment by vertical keiretsu } \\
\text { members }\end{array}$ & $\begin{array}{c}0.001 \\
(0.025)\end{array}$ & $\begin{array}{l}0.119^{* * *} \\
(0.033)\end{array}$ & $\begin{array}{c}-0.004 \\
(0.158)\end{array}$ & $\begin{array}{l}0.576^{* * *} \\
(0.181)\end{array}$ \\
\hline Investment by industry & $\begin{array}{l}0.036^{* * *} \\
(0.013)\end{array}$ & $\begin{array}{l}0.076^{* * *} \\
(0.021)\end{array}$ & $\begin{array}{l}0.192^{* * *} \\
(0.070)\end{array}$ & $\begin{array}{l}0.213^{* * *} \\
(0.083)\end{array}$ \\
\hline \multicolumn{5}{|l|}{ Information Variables } \\
\hline $\begin{array}{l}\text { Investment by horizontal keiretsu } \\
\text { members }\end{array}$ & $\begin{array}{l}0.035^{* *} \\
0.016)\end{array}$ & $\begin{array}{c}0.023 \\
(0.035)\end{array}$ & $\begin{array}{l}0.192^{* *} \\
(0.088)\end{array}$ & $\begin{array}{c}-0.127 \\
(0.142)\end{array}$ \\
\hline Investment by firm & $\begin{array}{l}0.076^{* * *} \\
(0.018)\end{array}$ & $\begin{array}{l}0.041^{* * *} \\
(0.013)\end{array}$ & $\begin{array}{l}0.435^{* * *} \\
(0.116)\end{array}$ & $\begin{array}{l}0.244^{* *} \\
(0.096)\end{array}$ \\
\hline Region Dummies & Yes & Yes & Yes & Yes \\
\hline Log Likelihood & -3174.04 & -3168.56 & -3176.84 & -3178.02 \\
\hline Chi-squared statistic & $773.68^{* * *}$ & $784.62^{* * *}$ & $768.08^{* * *}$ & $765.71^{* * *}$ \\
\hline Pseudo $\mathrm{R}^{2}$ & 0.11 & 0.11 & 0.11 & 0.11 \\
\hline Number of observations & 16335 & 16335 & 16335 & 16335 \\
\hline
\end{tabular}

NOTES: Standard errors in parentheses. $* * *, * *$ and $*$ denote statistical significance (two-tailed test) at the 1, 5 and 10 percent levels, respectively. 
Table 4: Conditional Logit Estimates of the Effect of Stock of Investment by Keiretsu Members on a Firm's Location Choice: Sensitivity Tests

\begin{tabular}{|c|c|c|c|c|}
\hline \multirow[b]{2}{*}{ Regressors } & \multicolumn{2}{|c|}{$\begin{array}{c}\text { Differential Effects for } \\
\text { Presidential Council } \\
\text { Members in Most Cohesive } \\
\text { Horizontal Keiretsu }\end{array}$} & \multicolumn{2}{|c|}{$\begin{array}{c}\text { Replacing Region Dummies } \\
\text { with Region-Year } \\
\text { Dummies } \\
\end{array}$} \\
\hline & $\begin{array}{c}\text { Previous- } \\
\text { Year Flows }\end{array}$ & Stock & $\begin{array}{c}\text { Previous- } \\
\text { Year Flows }\end{array}$ & Stock \\
\hline \multicolumn{5}{|l|}{ Agglomeration Variables } \\
\hline $\begin{array}{l}\text { Investment by vertical keiretsu } \\
\text { members }\end{array}$ & $\begin{array}{c}0.001 \\
(0.025)\end{array}$ & $\begin{array}{l}0.119^{* * *} \\
(0.033)\end{array}$ & $\begin{array}{c}0.000 \\
(0.026)\end{array}$ & $\begin{array}{l}0.117^{* * *} \\
(0.034)\end{array}$ \\
\hline Investment by industry & $\begin{array}{l}0.036^{* * *} \\
(0.013)\end{array}$ & $\begin{array}{l}0.076^{* * *} \\
(0.021)\end{array}$ & $\begin{array}{c}0.022 \\
(0.013)\end{array}$ & $\begin{array}{l}0.074^{* * *} \\
(0.021)\end{array}$ \\
\hline \multicolumn{5}{|l|}{ Information Variables } \\
\hline $\begin{array}{l}\text { Investment by horizontal } \\
\text { keiretsu members }\end{array}$ & $\begin{array}{l}0.019 \\
(0.019)\end{array}$ & $\begin{array}{l}0.013 \\
(0.038)\end{array}$ & $\begin{array}{c}0.006 \\
(0.019)\end{array}$ & $\begin{array}{l}0.005 \\
(0.039)\end{array}$ \\
\hline $\begin{array}{l}\text { Investment by horizontal } \\
\text { keiretsu members } * \text { Member } \\
\text { of Presidential Council in } \\
\text { cohesive keiretsu group }\end{array}$ & $\begin{array}{c}0.061^{*} \\
(0.034)\end{array}$ & $\begin{array}{c}0.054 \\
(0.078)\end{array}$ & $\begin{array}{c}0.060^{*} \\
(0.034)\end{array}$ & $\begin{array}{c}0.051 \\
(0.080)\end{array}$ \\
\hline Investment by firm & $\begin{array}{l}0.075^{* * *} \\
(0.018)\end{array}$ & $\begin{array}{l}0.040^{* * *} \\
(0.013)\end{array}$ & $\begin{array}{l}0.078^{* * *} \\
(0.018)\end{array}$ & $\begin{array}{l}0.043^{* * *} \\
(0.013)\end{array}$ \\
\hline Region Dummies & Yes & Yes & No & No \\
\hline Region-Year Dummies & No & No & Yes & Yes \\
\hline Log Likelihood & -3172.39 & -3168.32 & -3089.58 & -3081.12 \\
\hline Chi-squared statistic & $776.97^{* * *}$ & $785.12^{* * *}$ & $942.58^{* * *}$ & $959.51^{* * *}$ \\
\hline Pseudo $\mathrm{R}^{2}$ & 0.11 & 0.11 & 0.13 & 0.13 \\
\hline Number of observations & 16335 & 16335 & 16335 & 16335 \\
\hline
\end{tabular}

